\title{
PENGENALAN PAHLAWAN SAM RATULANGI PADA SISWA MI/SD
}

\author{
Hilda Zuhri Khairunnisa \\ Universitas Islam Negeri (UIN) Syarif Hidayatullah Jakarta \\ Email: hilda.zuhri19@mhs.uinjkt.ac.id \\ Orcid Id: \\ Anis Fuadah Z \\ Universitas Islam Negeri (UIN) Syarif Hidayatullah Jakarta \\ Email: anisfuadah.zuhri@uinjkt.ac.id \\ Orcid Id: 0000-0002-5935-030X
}

\begin{abstract}
English; 12 pt Cambria)
This article moots about a struggle of a famous and an influenced figure ever in that time, coming from Minahasa, North Sulawesi. He fought for Indonesia in his own way and got his thoughts gone viral even until now. His name is Gerungan Saul Samuel Jacob Ratulangi or usually called Sam Ratulangi. He also had the biggest role why Indonesia nowadays is called "Indonesia".

This article was made to 1) acquaint a biography of a patriot that is Gerungan Saul Samuel Jacob Ratulangi to learners, especially in elementary school. 2) acquaint the values in Sam Ratulangi. 3) know how Sam Ratulangi fought for his beloved country and what was his role in defending Indonesia. 4) acquaint his thoughts that is going viral even in nowadays. All of the data are gotten from books, literature, and journals that are related to the topic.
\end{abstract}

Keywords: education; opuses; behind the story of Merah-Putih; Si Tou Timou Tuтоu Tou.

\begin{abstract}
Abstrak
Artikel ini membahas tentang perjuangan seorang pahlawan terkenal dan paling berpengaruh pada masanya dari Minahasa, Sulawesi Utara. Dia berjuang untuk Indonesia dengan caranya sendiri. Dia memiliki pemikiran yang sangat terkenal bahkan hingga saat ini. Namanya adalah Gerungan Saul Samuel Jacob Ratulangi atau yang biasa dikenal dengan nama Sam Ratulangi. Dia juga memiliki peranan paling besar kenapa Indonesia dikenal dengan nama "Indonesia".

Artikel ini dibuat dengan maksud: 1) Memperkenalkan biografi sosok pahlawan Gerungan Saul Samuel Jacob Ratulangi atau yang biasa dikenal dengan nama Sam Ratulangi kepada peserta didik SD/MI di Indonesia. 2) Memperkenalkan nilai-nilai kepahlawanan yang ada pada Sam Ratulangi. 3) Bagaimana peran serta yang Sam Ratulangi ambil dalam memperjuangkan Indonesia. 4) Memperkenalkan hasil pemikirannya yang menjadi viral hingga saat ini. Data yang ada dalam artikel ini didapat dari buku dan jurnal yang berkaitan dengan pembahasan yang ada.
\end{abstract}


Kata Kunci: Pendidikan; Karya Ciptaan; Peristiwa Merah-Putih; Si Tou Timou Tumou Tou.

\section{A. PENDAHULUAN}

Sejarah merupakan bagian dari kehidupan manusia yang terjadi secara kronologis dan benar-benar terjadi pada masa lampau dengan didukung buktibukti yang nyata. Generasi yang biasa melupakan sejarah salah satunya adalah generasi muda, bahkan bisa dianggap lari dari dan meninggalkan sejarah. Mereka lebih memilih modernisasi dan melupakan tradisi, mereka mengagungkan globalisasi tetapi melupakan lokalitas, mereka menjiwai masa kini tapi melupakan bahkan meremehkan masa lalu.

Penting bagi kita untuk menghargai masa lalu. Dengan adanya masa lalu, kita bisa mengetahui peristiwa-peristiwa penting yang pernah terjadi. Peristiwaperistiwa penting tersebut nantinya bisa kita evaluasi dan ambil hikmah serta menjadikannya pembelajaran agar tidak mengulanginya lagi di masa depan. Mempelajari sejarah sangatlah bermanfaat. Manfaatnya di antara lain adalah menambah wawasan dan membuka pandangan terhadap dunia, melatih diri menjadi kritis, serta belajar sejarah juga dapat menginspirasi lewat tokoh-tokoh yang berperan penting dalam suatu peristiwa bersejarah.

Pengenalan tokoh sejarah sangatlah penting. Hal ini dikarenakan bagaimana untuk mengingat kembali kisah perjuangan para pendahulu, Mereka mengerahkan seluruh jiwa, tenaga, harta, bahkan waktu yang seharusnya utuk keluarga hanya untuk mempertahankan dan memerdekakan Indonesia. Mereka rela mengorbankan seluruh hidupnya untuk Indonesia. Jasa-jasa mereka tidak akan pernah bisa dilupakan begitu saja. Salah satu pahlawan tersebut adalah Dr. Gerungan Samuel Jacob Ratulangi.

Dr. Gerungan Saul Samuel Jacob (G.S.S.J) Ratulangi atau yang biasa dikenal dengan nama Sam Ratulangi (Salomon Ratulangie dalam bahasa Inggris) adalah seorang politikus, jurnalis, dan guru asal Minahasa (area yang mayoritas penduduknya Kristen), Sulawesi Utara. Sam Ratulangi adalah salah satu pahlawan termahsyur di kota asalnya. Selain itu, Sam Ratulangi juga merupakan matematikawan serta doktor ilmu pasti pertama di Indonesia. Ia dikenal dengan filsafatnya Si Tou Timou Tumou Tou yang berarti, "manusia baru dapat dikatakan manusia apabila telah memanusiakan manusia." Beliau mempunyai peranan besar atas kemerdekaan Indonesia salah satunya adalah menyebarkan berita proklamasi kemerdekaan yang telah dibacakan oleh Ir. Soekarno. Sam Ratulangi juga termasuk dalam anggota Panitia Persiapan Kemerdekaan Indonesia (PPKI) yang berhasil merumuskan Undang-undang Dasar (UUD) 1945. Sam Ratulangi juga merupakan gubernur Sulawesi pertama. 


\section{Gambar 1. Potret Sam Ratulangi yang terdapat pada uang Rp. 20.000,-}

Gambar diambil dari galeri pribadi oleh Hilda Zuhri pada 29 Maret 2020 pukul 12:29 WIB di Jakarta.

Karena banyak prestasi yang telah beliau raih, akhirnya beliau dikenang lewat cetakan uang Rp. 20.000,- emisi 2016 yang dikeluarkan pada 19 Desember 2016. Selain itu, namanya juga diabadikan pada sebuah bandara yang dinamakan Bandara Sam Ratulangi Manado, jalan raya utama yang bernama Jalan Sam Ratulangi dan Urutan Sam Ratulangi, serta Universitas Sam Ratulangi (UNSRAT) di Manado, Sulawesi Utara.

Sam Ratulangi menerima berbagai penghargaan yang diberikan langsung oleh Soekarno, antara lain Bintang Gerilya, Bintang Satya Lantcana, Bintang Mahaputra (Tingkat II) dan gelar Pahlawan Nasional (Ratulangi et al., 2019). Tokoh paling berpengaruh dengan nama lengkap Gerungan Saul Samuel Jacob Ratulangi ini merupakan salah satu orang yang sangat berjasa terhadap bangsa dan tanah air. Sam Ratulangi adalah sosok yang membuat sebutan yang dulunya Hindia-Belanda ini menjadi "Indonesia".

\section{B. METODOLOGI [12 pt. Cambria Bold]}

Kajian dalam artikel ini menggunakan metode studi pustaka. Menurut M. Nazir dalam bukunya yang berjudul 'Metode Penelitian', ia menyatakan bahwa studi kepustakaan adalah Teknik pengumpulan data dengan cara mempelajari dan menelaah bacaan pada buku-buku, literatur-literatur, catatan-catatan, dan laporanlaporan yang berkaitan dengan permasalahan yang menjadi objek penelitian.

Melakukan penelitian berarti mencari solusi atas pemecahan masalah yang dilakukan dengan cara ilmiah yang bersumber dari buku bacaan, literatur, ensiklopedia, karangan ilmiah, dan sumber lain yang terpercaya, baik dalam bentuk tulisan atau dengan format digital yang erat hubungannya dengan permasalahan yang sedang diteliti. 
Studi Pustaka biasanya dilakukan sebelum penulis melakukan penelitiannya. Hal ini bertujuan agar si penulis dapat mengambil hal yang relevan dengan penelitiannya serta menambah wawasan dan pengetahua si penulis. Studi Pustaka juga dapat membantu menemukan masalah apabila belum menemukan apa yang akan ditelti. Studi Pustaka dilakukan untuk memperoleh landasan teori yang dapat dijadikan pedoman dan menghindari adanya kesamaan penulisan (plagiarisme) yang telah diteliti sebelumnya.

\section{HASIL DAN PEMBAHASAN}

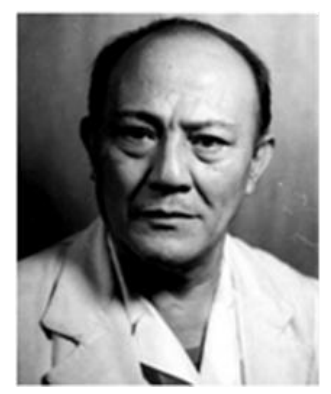

\section{Gambar 2. Sam Ratulangi}

Sumber: Google/Berdikari Online

http://www.berdikarionline.com/nasionalisme-sam-ratulangi/

Gerungan Saul Samuel Jacob (GSSJ) Ratulangi adalah seorang politikus, jurnalis dan guru paling berpengaruh dari Minahasa, Sulawesi Utara, Indonesia. Sam Ratulangi merupakan gubernur Sulawesi pertama. Ia pernah menjabat sebagai penasehat Minseifu sekaligus anggota dari Panitia Persiapan Kemerdekaan Indonesia (PPKI).

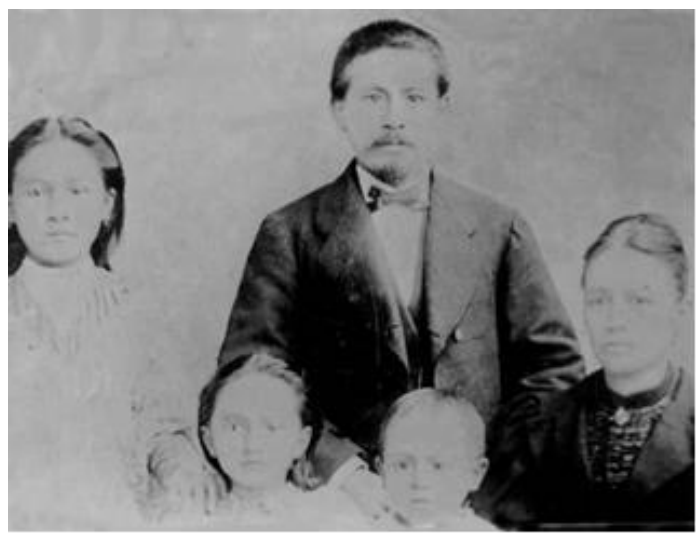

Gambar 3. Foto Keluarga Ratulangi

Sumber: Google/Jelajah Sejarah Manado

http://adrianuskojongian.blogspot.com/2015/11/hebatnya-keluarga-

ratulangi.html 
Gerungan Saul Samuel Jacob (G.S.S.J) Ratulangi atau yang biasa dipanggil Sam Ratulangi lahir pada 5 November 1890 di Tondano. Sam lahir dari keluarga yang terpandang. Ayahnya yang bernama Jozias Ratulangi merupakan seorang cerdikiawan. Jozias juga merupakan seorang guru yang cerdas. Jozias pernah dikirim ke Belanda untuk melanjutkan pendidikannya di Rijkskweekschool Haarlem (Ratulangi et al., 2019). Jozias berhasil mendapatkan ijazah Hoofkade. Ijazah Hoofkade merupakan ijazah yang digunakan oleh para guru untuk mengabdi dan mengajar di sebuah sekolah. Setelah lulus, Jozias kembali ke Indonesia lalu mengajar hingga akhirnya ia diangkat menjadi kepala sekolah di Hoofdenschool. Hoofdenschool adalah sebuah sekolah setara SMA yang hanya diperuntukan para raja dan bangsawan (Saul et al., 1949). Sam memiliki ibu yang bernama Augustina Gerungan. Augustina Gerungan merupakan putri dari Mayoor Gerungan. Orangtua Sam menikah pada 1881 (Herdiana, 2013). Mereka dikaruniai tiga orang anak. Sam-yang merupakan anak ketiga—juga memiliki dua orang kakak perempuan yang bernama Wulan Kajes Rachel Wihelmina Maria dan Wulan Rachel Wihelmina Marina. Ratulangi lahir sebagai putra bungsu dari kalangan aristokrat Minahasa, seorang ketua distrik Kasendukan.

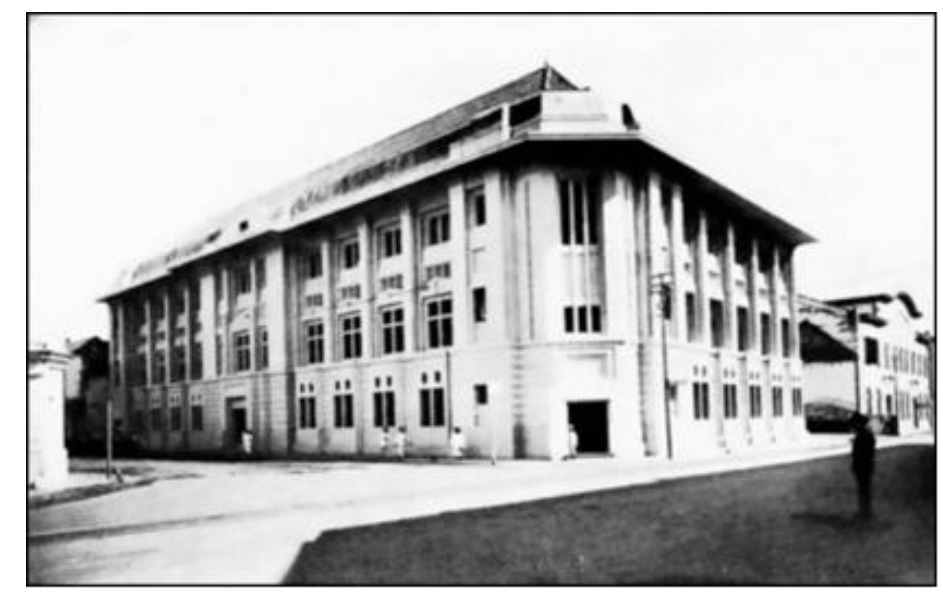

Gambar 4. Europeesche Lagere School

Sumber: Google/Jakarta.go.id

https://jakarta.go.id/artikel/konten/996/europeesce-lagere-school-els

Untuk anak-anak Eropa, ada tiga tingkat sekolah dasar yang dinamakan E.L.S. (Europeesche Lagere School) lama belajar enam tahun. Didirikan di Jakarta pada tahun 1816. Kemudian disekitar tahun 1900-1940 perkembangan jumlah sekolah dan murid tidak mengalami perkembangan yang berarti, akan tetapi setelah tahun 1900 jumlah anak-anak pribumi yang memasuki E.L.S. meningkat (Nasution, 2011). 
Sebagai seorang aristokrat dia bisa masuk Europesche Lagere School, ELS. Sam Ratulangi memulai pendidikannya di Sekolah Dasar Belanda (Europeesche Lagere School) pada 1898 di Tondano.

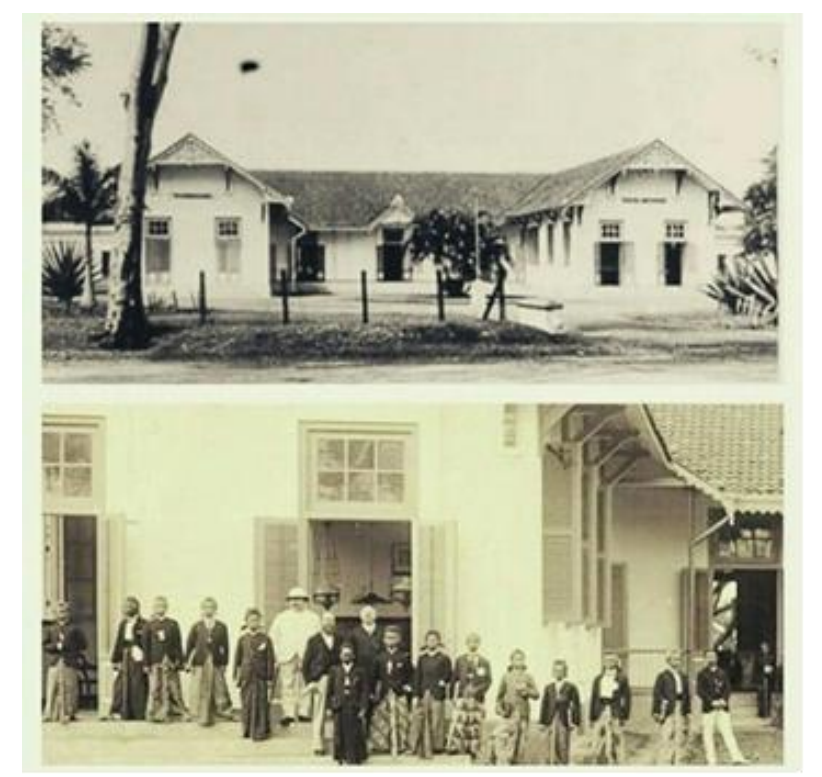

Gambar 5. Hoofdenschool

Sumber: Google/Pinterest

https://id.pinterest.com/pin/325807354270649787/

Lalu, setelah menamatkan sekolah dasar dia masuk Hoofdenschool, sebuah sekolah elit lokal untuk pendidikan kaum ambtenaar, terbatas hanya untuk kalangan atas. Sam melanjutkan studinya di Sekolah Menengah Hoofdenschool di Tondano pada 1903. Hoofdenschool merupakan sekolah terbaik se-Indonesia Timur, sehingga Hoofdenschool mendapat julukan "Sekolah Radja" (Herdiana, 2013). Karena kecerdasannya, Sam berhasil mendapat beasiswa untuk melanjutkan studinya di Batavia (sekarang bernama Jakarta) (Ratulangi et al., 2019). 


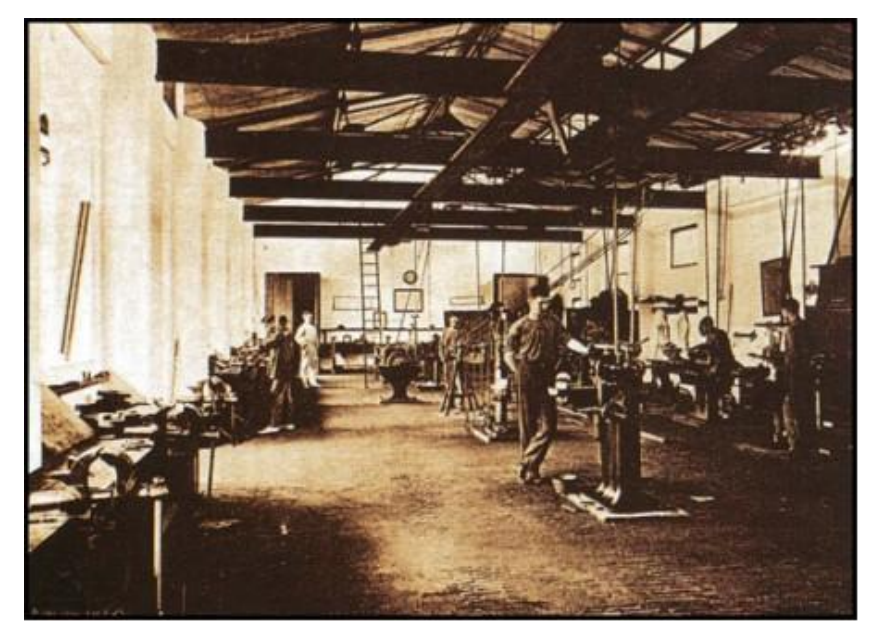

Gambar 6. Koningen Wilhelmina School di Jakarta

Sumber: Google/Jakarta.go.id

https://jakarta.go.id/artikel/konten/1873/koningen-wilhelmina-schoolgedung

Setelah lulus dari Hoofdenschool, Sam berniat untuk melanjutkan studinya di Sekolah Dokter Hindia (Matematika et al., 2015). STOVIA, Sekolah tot Opleiding van Indische Artsen, yang mendidik dokter-dokter Jawa di Batavia. Ketika ada penawaran beasiswa dari STOVIA, Ratulangi mendaftar dan memenangkan beasiswa. Itulah saat pertama kalinya dia meninggalkan tanah kelahirannya Minahasa menuju Jawa setelah mendapat beasiswa dari sekolah tersebut. Namun, setelah Sam sampai di Jakarta, Sam mengurungkan niatnya. Akhirnya pada 1904, Sam memutuskan untuk melanjutkan studinya di Sekolah Teknik Koninlijke Wilhelmina School (Herdiana, 2013) dan mengambil jurusan mesin (Ratulangi et al., 2019). Sam lulus dari sekolah tekniknya pada 1908 dengan nilai terbaik. Sehingga, dirinya punya kesempatan bekerja di Jawatan Kereta Api Lin Barat, yang memuat jalur Priangan Selatan hingga Maos di Cilacap di daerah Priangan Selatan sebagai ahli Teknik mesin (Salim, 2017). Sam juga terlibat dalam pembuatan jalur kereta api dari Garut ke selatan, melalui Rawah Lakbok ke Maos hingga ke Cilacap (Ratulangi et al., 2019).

Sam merasa sangat bahagia karena bisa mendapatkan pekerjaan. Namun kebahagiaannya tidak berlangsung lama. Selama bekerja di perusahaan tersebut, Sam selalu saja dikucilkan. Gajinya selalu lebih kecil dibanding karyawankaryawan lain yang merupakan keturunan Indonesia-Belanda (Eurasia). Semua hal tersebut didapatkan oleh Sam hanya karena ia merupakan seorang pribumi. Hal ini menjadikannya bersemangat dan tidak putus asa. Sam bertekad untuk melanjutkan pendidikan ke jenjang yang lebih tinggi lagi (Matematika et al., 2015). 
Akhirnya pada 1913, Sam memutuskan untuk berangkat ke Eropa dengan kapal. Bersama dengan penumpang kapal lain yang saat itu memiliki tujuan ke Belanda, Sam turun di Napoli, Italia. Kemudian, Sam melanjutkan perjalanannya ke Amsterdam menaiki kereta api. Sam juga pernah bekerja pada salah satu dermaga untuk melengkapi dana dan menambah pemasukannya selama ia hidup dan tinggal di Belanda. Menjelang mulainya tahun kuliah, Sam mendaftarkan dirinya pada Fakultas Ilmu Pasti. Sam lulus dan berhasil memperoleh ijazah ilmu pasti pendidikan sekolah menengah (Middelbare Acte Wiskunde en Paedagogiek) (Ratulangi et al., 2019). Berbekal ijazah tersebut, Sam melanjutkan kuliahnya dan mengambil jurusan Ilmu Alam di Vrije Universiteit van Amsterdam, Belanda. Sam selama dua tahun (Ratulangi et al., 2019). Di sini pula, Sam dipercayai oleh teman-temannya untuk mempin sebuah organisasi bernama Indische Vereeninging dari tahun 1914. Pada 1915, Sam lulus dari Universiteit van Amsterdam sebagai guru Ilmu Pasti.

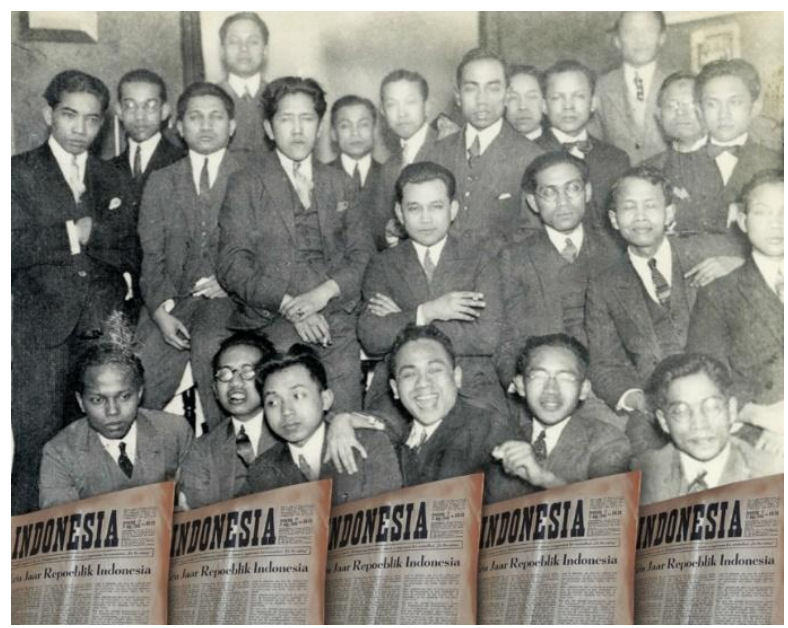

Gambar 7. Indische Vereeninging

Sumber: Google/Zikri Fadila Wordpress

https://zikrifadila.wordpress.com/2016/09/27/perhimpunan-indonesia/

Indische Vereeninging adalah organisasi mahasiswa-mahasiswa di negeri Belanda. Organisasi ini didirikan dengan azas tujuan "memajukan kepentingan bersama orang Hindia di Belanda dan menjaga hubungan dengan Hindia Timur Belanda" (Utama, 2018). Generasi muda mahasiswa Indonesia di Belanda dengan cepat mendominasi Indische Vereeninging. Di dalam organisasi mahasiswamahasiswa tersebut telah terjadi perubahan mendasar yang menjadi pertanda bahwa akan terjadi perubahan orientasi dalam organisasi itu, yaitu mengubah namanya yang semula adalah Indische Vereeninging menjadi Indonesische Vereeniging (Perhimpunan Indonesia) pada 1922. Nama baru tersebut menyatakan dengan tegas sebuah sikap yang lebih kuat lagi bahwa orang-orang Indonesia bukan lagi menjadi bagian dari Hindia-belanda (Ingleson, 1993: 7). Darmawan 
Mangoenkoesomo menyatakan, "mulai dari sekarang kita membangun Indonesia dan meniadakan Hindia atau Nederlands-Indie" (Hatta, 2011: 166). Menurut Poeze (2008: 174) Indonesische Vereeniging secara pasti telah meninggalkan masa lalunya sebagai "perhimpunan untuk bersenang-senang". Di bawah ketua baru Iwa Koesoema Soemantri organisasi ini mengemukakan tiga asas pokok yang menjadi pegangan tetap bagi Indonesische untuk tahun- tahun mendatang: kemerdekaan bagi Indonesia, self-help, dan perjuangan ke arah kesatuan (Poeze, 2008: 174). Asas perjuangan yang lebih radikal ini kemudian disalurkan ke dalam media propaganda mereka yang turut diganti namanya dari Hindia Poetra menjadi Indonesia Merdeka. Dalam pendahuluan edisi perdana Indonesia Merdeka, disebutkan bahwa perubahan nama ini mengungkapkan tujuan dan usaha dari organisasi ini, yaitu merdeka! Ditambah lagi kata Indonesia Merdeka diharapkan dapat menjadi semboyan yang menarik bagi pemuda Indonesia untuk berjuang mencapai kemerdekaan (Blumberger 1931: 187; Poeze, 2008: 175).

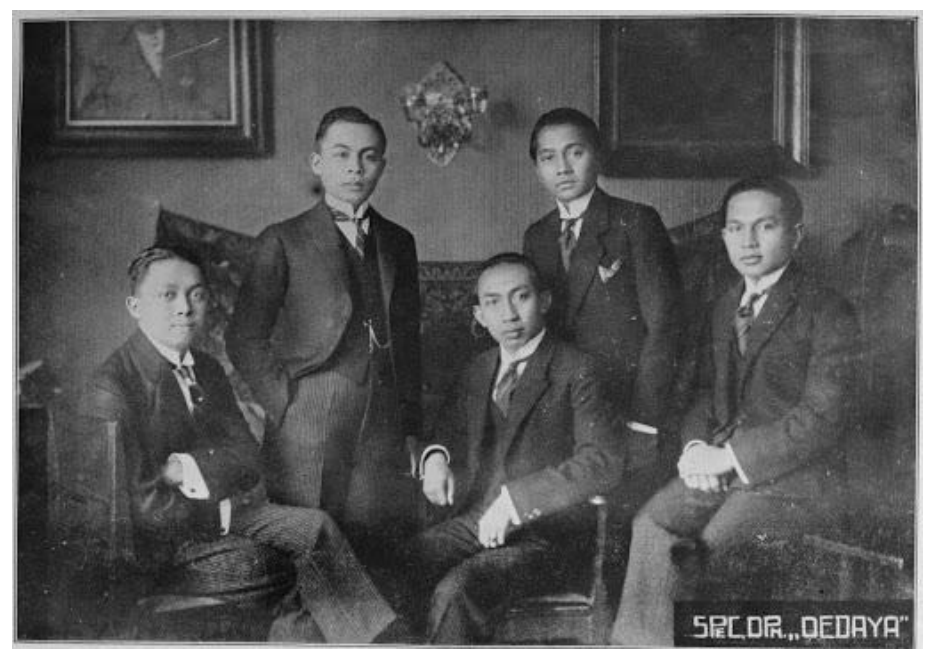

Gambar 8. Pengurus Indonesische Vereeniging

Sumber: Google/kasunanan

http://kasunanan.com/pengurus-indonesische-vereeniging.html

Salah satu strategi yang disepakati oleh para pemimpin Perhimpunan Indonesia (PI) dalam memperluas propaganda Gerakan kemerdekaan Indonesia adalah membangun jaringan dengan gerakan antikolonial Asia dan Afrika, terutama yang berada di Eropa. Selain itu, hubungan antara mahasiswa pengurus Perhimpunan Indonesia dengan organisasi mahasiswa Indonesia dan Malaysia di Kairo juga dijaga dan diperkuat (Ingleson, 1993: 45). Upaya untuk membangun koneksi dengan dunia internasional pernah dilakukan sebelumnya oleh anggota PI, yaitu Sam Ratulangi, yang mendirikan organisasi sekaligus pemimpin PanAsia Société Asiatique des Étudiants (Masyarakat Mahasiswa Asia) di Zürich. Di dalam organisasi ini terdapat mahasiswa-mahasiswa dari Korea, Jepang, Cina, 
Siam, Filipina Muangthai, India, Indonesia dan lain-lain negara di Asia pada 1918. Masih dengan format yang sama, namun kali ini lebih berorientasi politis dan radikal, Perhimpunan Indonesia menghubungkan gerakan antikolonial Indonesia dengan organisasi antikolonial Asia dan Afrika. Arnold Mononutuyang merupakan Wakil Ketua PI saat itu —-mengatakan, "di bawah kepemimpinan Soekiman, mahasiswa Indonesia harus bekerjasama dengan mahasiswa yang berasal dari negara lain terutama Asia dan Afrika yang statusnya adalah sebagai bangsa terjajah" (Nalenan, 1981: 57).

Di Belanda, Sam berhubungan dengan para tokoh pergerakan Indonesia seperti Ki Hajar Dewantara, Cipto Mangunkusumo dan Douwes Dekker. Dari sinilah semangat nasionalismenya mulai tumbuh. Tak luput dari itu mereka sering melaksanakan rapat-rapat yang membicarakan tentang keadaan Hindia Belanda (Sebutan untuk Indonesia sebelumnya) di masa itu. Di sana pula, Sam bertemu dan berkenalan dengan Size Houtman yang nantinya menjadi istrinya.

Setelah cukup lama tinggal di Belanda, Sam menikah dengan seorang wanita Belanda, Dr. Suze Houtman. Ia merupakan seorang psikiater. Mereka dikaruniai dua orang anak-Cornelis (Oddy) Ratulangi dan Emily (Zus) Ratulangi. Pernikahan mereka tidak bertahan lama, dan akhirnya keduanya memutuskan untuk bercerai, sementara hak pengasuhan anak jatuh ke tangan Sam. Untuk mencukupi kebutuhan hidup, Sam bekerja sebagai wartawan. Dan, sebagai seorang ayah, Sam menyadari pentingnya kasih seorang ibu untuk anakanaknya. Oleh karena itu, dia memutuskan untuk menikah lagi dengan seorang wanita putri pasangan Jan Nicolaas Tambayong dan Fransina Everdina Lefrandt, Maria Catharina Josephine 'Tjen` Tambajong. Dari pernikahannya yang kedua, Sam dianugerahi 3 orang putri Milly Ratulangi, Lany Ratlangi, dan Uky Ratulangi.

Sam ingin meneruskan ke tingkat S3 (Program Doktor) di Universitas Amsterdam. Tapi, Sam ditolak oleh Dewan Universitas karena berbagai alasan. Berdasarkan saran dari Mr. Abendanon, mantan menteri pendidikan di Hindia Belanda-di tahun yang sama-Sam akhirnya melanjutkan studinya ke Swiss. Sam lulus dengan desertasinya yang berjudul "Kurven-Systeme in Vollstandigen Figuren" dan mendapat gelar Doktor der Natur-Philosophie (Dr. Phil) untuk Ilmu pasti dan Ilmu Alam di Universitas Zürich pada tahun 1919.

Setelah menuntut ilmu di Eropa, Sam Ratulangi kembali ke tanah air tercinta, Indonesia. Pada 1919, ia mengajar di Prinses Juliana School (setara STM) dan Algemeene Middelbare School (setara SMA) di Yogyakarta. Namun ternyata, pada saat itu banyak murid keturunan Belanda yang bersekolah di sekolah-sekolah tersebut. Pada kala itu, Belanda sangat melarang pribumi untuk berkecimpung di dunia pendidikan, baik untuk menuntut ilmu maupun mengajar. Dan tentu saja hal ini mendapat perhatian dari orang-orang Belanda. Orang-orang 
Belanda-termasuk di antaranya adalah Zengraaf (wartawan Javabode) sangatlah geram. Mereka merasa bahwa Dr. Ratulangi belum pantas menjadi pengajar. Meski mendapat banyak kecaman, Sam Ratulangi tidak pernah menyerah. Semua kecaman yang didapatnya membuat semangat nasionalismenya semakin berkobar dan membara seperti api. Kemudian, Ratulangi sampai pada kesimpulan bahwa pendidikan belum sepenuhnya bisa menyalurkan semua citacitanya.

Tiga tahun kemudian, Ratulangi bersama dengan seorang temannyaTumbelaka - memutuskan untuk berangkat ke Bandung. Kemudian, mereka mendirikan sebuah tempat bernama 'Maskapai Asuransi Indonesia' di Bandung. Sam Ratulangi sendirilah yang memimpin dan mengendalikan maskapai tersebut dari tahun 1922 hingga 1924.

Pada suatu saat, Ir. Soekarno yang dulu masih seorang pelajar dari HBS Surabaya sedang berjalan-jalan di Bandung. Soekarno melihat sebuah papan nama bertuliskan Algemene Levensverzekering Maatschappij Indonesia di jalan Braga. Peristiwa tersebut mengawali perjumpaannya dengan Bung Soekarno yang dianggapnya sebagai guru dalam hal politik.

Sam Ratulangi menjabat sebagai sekretaris dewan Minahasa di Manado dari tahun 1924 sampai dengan tahun 1927. Jabatan tersebut ia gunakan untuk membuat usaha-usaha yang dapat menyejahterakan rakyat. Contohnya adalah membuka lahan baru untuk bertani, mendirikan yayasan dana belajar, dan yang lainnya. Perjuangannya pun tidak sia-sia. Salah satunya adalah membuat pemerintahan kolonial Belanda menghapuskan sistem kerja paksa di Minahasa. (Matematika et al., 2015)

Karena kegemilangannya pada 1927, Sam diangkat menjadi anggota Volksraad (Anggota Dewan Rakyat). Setelah menjadi anggota Volksraad, ia mengajukan tuntutan terhadap pemerintah Belanda agar segera menghapuskan perbedaan politik, ekonomi, serta Pendidikan antara orang Indonesia dan orang Belanda. Dr. Sam Ratulangi sangat berani dalam menyuarakan suaranya. Ia mengecam pemerintah kolonial Belanda yang pada saat itu melakukan pendiskriminasian terhadap bangsa Indonesia. Bahkan beliau disebut sebagai tokoh radikalis dan ekstrimis oleh bangsa Belanda. Pernah suatu saat terdapat kekeliruan dalam reis declaratie (biaya angkutan dan perjalanan) karena tidak sesuai dengan data yang ada. Akhirnya, Dr. Sam Ratulangi ditangkap dan mendekam di dalam penjara selama empat tahun, serta dipecat dari jabatannya sebagai anggota dewan rakyat.

Pada tahun yang sama, tepatnya pada 16 Agustus 1927, Dr. Sam Ratulangi bersama dengan dr. Tumbelaka mendirikan sebuah partai yang diberi nama "Partai Persatuan Minahasa". Partai ini awalnya merupakan partai lokal yang bertujuan untuk memperjuangkan kepentingan daerah tersebut. Namun lama- 
kelamaan, partai ini berkembang menjadi partai yang besar dan bertujuan menjadikan Indonesia merdeka.

Di tengah kesibukannya berpolitik, Sam Ratulangi mendirikan sebuah organisasi, yaitu "Persatuan Kaum Sarjana Indonesia". Selain itu, Sam juga selalu menerbitkan majalah mingguan. Keluasan wawasan Sam Ratulangi ditunjukkan melalui buku karangannya yang berjudul "Indonesia in de Pacifik Kernproblemen Van den Aziastichen" (Indonesia di Pasifik-Analisa Masalah-masalah Pokok Asia Pasifik).

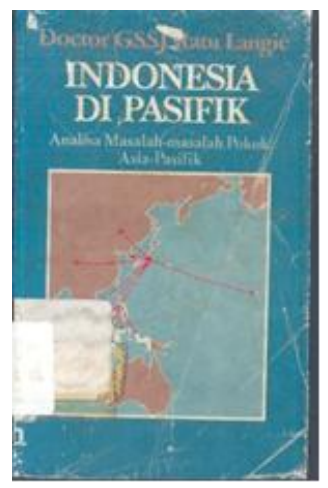

\section{Gambar 9. Salah satu karya hasil pemikiran Dr. Ratulangi}

Sumber: Google/Opac Perpusnas

https://opac.perpusnas.go.id/uploaded_files/sampul_koleksi/original/Mono graf/1563560.JPG?rnd=1576956031

Karena wawasannya yang sangat luas, akhirnya Sam Ratulangi menulis pemikiran terbesarnya dan dituangkan dalam bentuk buku pada tahun 1937. Buku itu kemudian diberi judul "Indonesia in de Pacifik Kernproblemen Van den Aziastichen" (Indonesia di Pasifik-Analisa Masalah-masalah Pokok Asia Pasifik). Menurut Ratulangi, Indonesia bagi Pasifik dan perekonomian dunia mengandung makna tiga hal yang bersifat pasif, yaitu: negeri konsumen, negeri sumber bahan mentah, dan negeri tempat penanaman modal (Nathan \& Scobell, 2012).

Bagi Dr. Ratulangie, sudah terjadi perpindahan modal yang sangat besar dari Eropa (yang dahulunya merupakan pusat keuangan dunia) ke Asia-Pasifik. Kedua raksasa ekonomi yaitu Amerika dan Jepang sudah tidak perlu lagi bergantung pada Eropa untuk kebutuhan modal mereka. Mereka sendiri sudah menjadi negara kreditor sebagai akibat dari perkembangan industry yang sangat cepat dan pesat. Perubahan pergeseran pusat keuangan inilah yang menurut Ratulangi menghasilkan suatu politik ekonomi baru, yaitu lingkungan Pasifik (de Pacific-sfeer). Dasar dari lingkungan baru ini adalah "New York-Tokyo" yang memanjang hingga ke Nanking dan Canton, serta mencakup seluruh Lautan Teduh. Lautan ini sudah tidak teduh lagi. Lautan ini sudah mulai ramai dan dipenuhi oleh kapal-kapal yang sudah mulai banyak melakukan pelayarannya. 
Kapal-kapal tersbut kebanyakan adalah kapal-kapal dagang dari berbagai negara dan kapal-kapal perang yang berasal dari Amerika, Inggris, Jepang, dan Perancis (Prof.C.P.F.Luhulima, 1937).

Dr. Sam Ratulangi sudah melihat potensi akan terjadinya peperangan di Asia. Sam dihadapkan oleh dua pilihan, yaitu bekerjasama dengan pemerintahan Jepang atau tidak. Jenderal Hideki Tojo meminta Sam supaya rakyat Indonesia mau membantu pemerintahan Jepang. Dwi tunggal, yaitu Soekarno dan Hatta ditunjuk oleh Sam Ratulangi sebagai orang yang tepat untuk menyelesaikan hal itu.

Sam Ratulangi selalu menuangkan pendapatnya pada majalah-majalah yang selalu diterbitkan setiap minggunya. Pendapat yang ia sampaikan mengenai adanya perbedaan dan pertentangan di antara tokoh-tokoh pergerakan. Maka dari itu, Sam selalu mengingatkan kepada seluruh pemimpin pergerakan nasional bahwa mereka belum sampai kepada tujuan dan bahwa pasti mereka akan mencapai tujuan itu.

Sebelum kemerdekaan diproklamirkan, organisasi perjuangan Sulawesi telah dibentuk pada bulan April 1945 dengan nama singkatan "Soedara" (Soember Darah Rakyat). Pada tanggal 10 Agustus 1945 diberangkatkanlah tiga utusan Soedara ke Jakarta yang dipimpin oleh Dr. Sam Ratulangi, dan anggotanya yaitu Andi Pangeran Petta Rani dan Andi Sultan Daeng Raja untuk pengesahan dan pengumuman UUD 1945 dan melakukan persiapan kemerdekaan Indonesia (Geometry \& Analysis, 1949).

Ketika sidang PPKI digelar pada 18 Agustus 1945 Sam Ratulangi kembali ke panggung politik. Sidang tersebut bertujuan untuk mengesahkan rancangan undang-undang dasar yang telah dibuat pada bulan Juli 1945.

Dr. Ratulangi diangkat menjadi Gubernur Sulawesi. Ia menduduki jabatannya sebagai gubernur hanya kurang dari satu tahun. Ia menjabat yakni terhitung sejak 17 Agustus 1945 hingga 5 April 1946. (Laessach M Pakutawo, Mustari Busro, 2014). Setelah beliau kembali ke Makassar, segala perhatian dan harapan masyarakat Sulawesi otomatis tertuju pada Sam. 


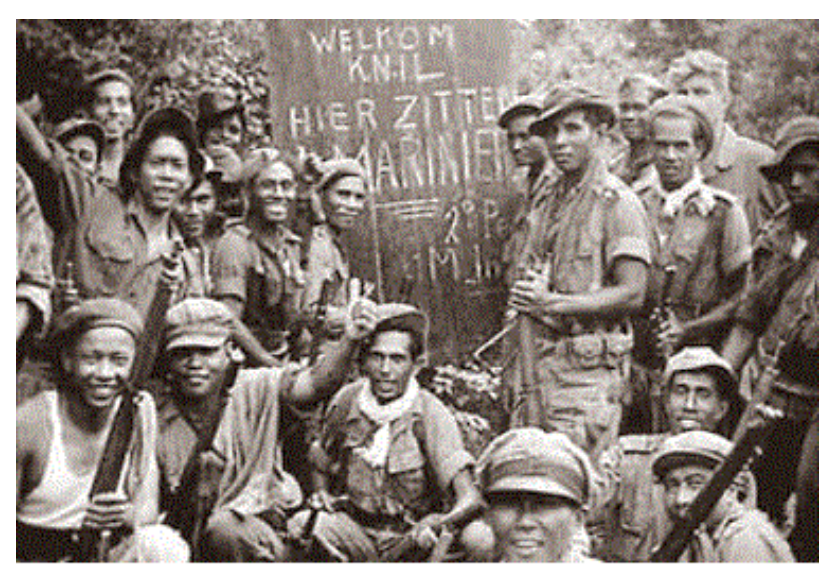

Gambar 10. Peristiwa Merah Putih

Sumber: Google/Kumpulan Studi Aspirasi

http://kumpulanstudi-aspirasi.com/history/peristiwa-merah-putih-pada-14februari-1946/

Pada 24 September 1945, pasukan sekutu mendarat di Makassar di bawah pimpinan Brigadir Jenderal Dougherty disertai oleh tentara NICA (Netherland Indies Civil Administration). NICA Belanda kemudian mengumpulkan mantan pelajar-pelajar sekolah menengah Jepang dalam rangka membujuk mereka masuk kembali ke sekolah Belanda. Pelajar-pelajar Jepang tersebut terdiri dari para pelajar Futsu Cugukko (Sekolah Menengah Umum), Tokobetsu Cugukko (Sekolah Menengah Istimewa), dan Riu Gaksei (calon mahasiswa untuk dikirim ke Jepang).

Para pelajar yang juga adalah pejuang kemerdekaan menolak masuk ke sekolah Belanda walaupun mendapat ancaman keras dari pimpinan NICA, Major J.Wegner. Para pelajar hampir setiap hari mereka berkumpul di rumah Dr. Ratulangi, di situlah tercetus ide untuk mendirikan sekolah sendiri. Setelah dirundingkan dengan para pimpinan perjuangan — antara lain Dr. Ratulangi, Lanto Daeng Pasewang, Sam, Mr. Zainal Abidin, Siranamuel, Saelan, dan Mr. Tadjudin Nur-akhirnya mereka semua setuju untuk membangun sebuah sekolah.

Akhirnya, pada tanggal 8 Oktober 1945 para tokoh pergerakan nasional di Makassar mendirikan sebuah "Perguruan Nasional" yang bertujuan memupuk semangat kebangsaan dan menghasilkan kader bangsa bagi pemuda-pemuda yang ada di Makassar (Hermiyanty, Wandira Ayu Bertin, 2017). Kebanyakkan pelajarnya adalah pelajar sekolah menengah pertama. Perguruan Nasional dipimpinan langsung oleh Dr. Ratulangi. Guru-gurunya adalah para pimpinan Republikein sehingga SMP Nasional dijuluki sekolah perjuangan. Selain itu, Perguruan Nasional juga disebut sebagai sekolah tertua di Indonesia Timur. Hingga saat ini, Perguruan Nasional telah tersedia untuk Sekolah Dasar, Sekolah Menengah Pertama, Sekolah Menengah Awal, hingga Sekolah Menengah 
Kejuruan. Sekolah Perguruan Nasional berlokasi di J1. DR. Ratulangi No.84, Mariso, Kec. Ujung Pandang, Kota Makassar, Sulawesi Selatan 90125.

Saat menjabat sebagai gubernur, Sam Ratulangi memerintahkan pembentukan Badan Perjuangan Pusat Keselamatan Rakyat. Dr. Sam Ratulangi membuat petisi yang ditandatangani oleh 540 kepala ketua masyarakat Sulawesi. Petisi itu berisikan bahwa seluruh rakyat Sulawesi tidak dapat dipisahkan dari Republik Indonesia. Dengan adanya petisi tersebut, pada 5 April 1946, Sam Ratulangi ditangkap oleh Belanda beserta para stafnya. Kemudian, Sam Ratulangi ditangkap dan dibuang ke Serui (Irian Barat).Tujuan penangkapan yang dilakukan oleh Belanda ini adalah untuk menghentikan perlawanan rakyat terhadap Belanda. Sam Ratulangi ditahan selama 3 bulan di Makassar. Kemudian Sam dibuang di Serui, Irian Jaya. Sam Ratulangi baru dibebaskan setelah adanya persetujuan Renville pada bulan Januari 1948. Setelah mengalami masa pembuangan, Sam Ratulangi langsung kembali ke Jawa.

Pada saat tentara sekutu akan menyerahkan Sulawesi ke tangan Belanda, Sam Ratulangi menentangnya. Sam mengajukan petisi kepada Perserikatan Bangsa-bangsa (PBB) supaya Sulawesi tetap bersatu dengan negara Republik Indonesia dan tidak diberikan kepada Belanda. Keputusan dari Sam Ratulangi memicu terjadinya konflik. Bentrok dengan Belanda pun tidak terelakan. Di Sulawesi Utara terjadi bentrokan yang dikenal dengan nama "Peristiwa Merah Putih di Manado". Hal yang sama juga terjadi di Sulawesi bagian Selatan, yaitu perlawanan pemuda pejuang. Para pemuda pejuang ini dipimpin oleh Robert Wolter Monginsidi.

Perisiwa Merah-Putih melibatkan rakyat Manado, Tomohon, dan Minahasa. Peristiwa ini berawal ketika Jepang secara resmi mengumumkan kekalahannya atas Sekutu. Karena kekalahannya itu-Jepang yang tadinya menduduki wilayah Sulawesi-maka Jepang harus memberikan wilayah yang sempat didudukinya tersebut kepada Sekutu. Namun pada 21 Agustus 1945, Jepang ternyata sudah memberikan Sulawesi kepada E.H.W Palengkahu yang merupakan pembesar Barisan Pemuda Nasional Indonesia (PBNI).

Tapi ternyata, BPNI diam-diam telah bekerja sama dengan Koninklijk Nederlands Indisch Leger (KNIL). Sedangkan, KNIL sendiri adalah barisan atau pasukan bersenjata yang dibentuk oleh belanda. KNIL akan selalu bertindak atas perintah Belanda. Namun, akhirnya KNIL sadar dan kembali berpihak pada Indonesia untuk bersatu melawan penjajah.

Peristiwa merah putih di mulai dengan pendaratan tentara ANFEI di Manado, yang diboncengi pasukan NICA tiba di Manado. Mereka segera mempersenjatai bekas pasukan KNIL Belanda yang sempat menjadi tawanan Jepang. Mereka ini dikenal sebagai tangsi putih. Pasukan NICA bertindak sewenang-wenang. Mereka menangkapi para tokoh Republik Indonesia. Tindakan 
ini tentu saja mengundang reaksi bekas anggota KNIL Indonesia. Mereka ini disebut sebagai tangsi hitam.

Para pemuda yang tergabung dalam pasukan KNIL kompi VII di bawah pimpinan Letkol Charles Choesoy Taulu bersama dengan rakyat menyerbu markas NICA di Teling. Mereka berhasil menawan sekitar 600 orang pasukan dan pejabat Belanda. Mereka juga berhasil membebaskan para pejuang yang ditawan NICA. Mereka juga melakukan perebutan kekuasaan di Manado, Tomohon, dan Minahasa pada tanggal 14 Februari 1946. Selain itu juga, mereka berhasil merebut bendera Belanda. Bendera Belanda tersebut kemudian di robek sehingga yang tertinggal hanyalah warna merah dan putih.

Mayor Wuisan memimpin para pemimpin dan pemuda untuk menyusun pasukan keamanan untuk memperkuat kedudukan Republik Indonesia. Kemudian pasukan tersebut diberi nama Pasukan Pemuda Indonesia (PPI). Bendera Merah Putih kemudian dikibarkan di seluruh pelosok Minahasa hampir selama satu bulan, yaitu terhitung sejak tanggal 14 Februari 1946.

Pada tanggal 16 Februari 1946, dikeluarkan selebaran yang menyatakan bahwa kekuasaan atas Manado telah berada di tangan bangsa Indonesia. Akhirnya NICA dapat disingkirkan dari Sulawesi Utara. Dan pada tanggal 16 Februari 1946, dibentuklah pemerintahan sipil dengan B.W. Lapian sebagai residen.

Dalam menentang keputusan pemerintahan kolonial Belanda, tentang pemisahan Indonesia bagian timur dengan Republik Indonesia, bersama Mr. I Gusti Ketut Puja, Ir. Pangeran Muhammad Noor, Dr. T.S.T. Diapari, W.S.T. Pondang, Suakrdjo Wirjopranoto, Sam Ratulangi mengeluarkan sebuah pernyataan yang dikenal dengan nama "Manifes Ratulangi". Pernyataan tersebut disiarkan di RRI Yogyakarta pada 10 November 1948. Inti pernyataan tersebut adalah seruan kepada para pemimpin Indonesia bagian timur agar menentang segala upaya untuk memisahkan Indonesia bagian timur dengan Negara Kesatuan Republik Indonesia (NKRI).

Ketika Belanda melancarkan serangan agresi militer yang kedua, Belanda kembali berhasil menangkap Dr. Sam Ratulangi, tujuan penangkapan Dr. Sam Ratulangi oleh belanda adalah untuk menghentikan perlawanan rakyat indonesia terhaadap belanda. Saat menjalani masa tahanan, dan ditengah perjuangan Rakyat Indonesia untuk mempertahankan kemerdekaan, Dr. Sam Ratulangi meninggal dunia pada tanggal 30 Januari 1949 di Jakarta, jenazahnya dimakamkan di pemakaman umum Tanah Abang. Kemudian makam itu dipindahkan kemakam keluarga di Tondano. Setelah beliau meninggal, kini namanya diabadikan pada nama Banda Udara di Manado yaitu Bandara Sam Satulangi, Universitas Negeri di Sulawesi Utara yaitu Universitas Sam Ratulangi, serta nama jalan di Ujung Padang, Kota Makassar dan di Kediri, Jawa Timur. 
Si Tou Timou Tumou Tou adalah pemikiran yang sangat terkenal di antara kalangan masyarakat Sulawesi. Si Tou Timou Tumou Tou sendiri berarti, "manusia dapat dikatakan manusia apabila memanusiakan manusia." Sebenarnya pemikiran ini merupakan salah satu falsafah tua yang diturunkan dari suatu generasi ke generasi selanjutnya. Filsafah tua tersebut berbunyi, “Akad Se Tu Us Tumouw O Tumouw Toow" yang artinya "sampai keturunan hidup, ia harus menghidupkan sesama manusia. Si Tou Timou Tumou Tou merupakan filosofi Sam Ratulangi yang bahkan masih terkenal hingga saat ini, tidak hanya di Masyarakat Sulawesi saja, tapi juga di seluruh negeri. Pemikiran filosofis ini mananami kehidupan masyarakat Minahasa bahkan seluruh masyarakat Sulawesi Utara, untuk selalu hidup rukun dan bertujuan memanusiakan manusia, bukan malah hidup dengan menjadi musuh terhadap sesama (Iii, 2013). Dr. Sam Ratulangi sebagai Tou Minahasa mampu melahirkan nilai-nilai budaya sehingga bisa memotivasi generasi selanjutnya untuk mengupayakan masa depan dan nilainilai spiritual. Ayahnya-Jozias Ratulangi-mewariskan pandangan hidup yang telah didapatkannya selama bersekolah di Belanda ini kepada Sam Ratulangi (Herdiana, 2013). Jadi, Dr. Ratulangi telah dibesarkan dengan nilai-nilai tersebut sedari ia masih kecil, ia dididik mensosialisasikan nilai-nilai luhur tersebut.

\section{KESIMPULAN}

Sam Ratulangi merupakan sosok tokoh yang sangat berpengaruh di Minahasa. Orang-orang di Minahasa sangat menghargai pendidikan, bahkan tidak sedikit dari para orang tua di Minahasa yang rela memberangkatkan anak-anaknya ke Eropa, terutama Belanda, untuk melanjutkan pendidikan mereka. Sam Ratulangi telah mengecap pendidikan di beberapa tempat dan mendapat banyak pengalaman. Sam Ratulangi juga aktif di beberapa organisasi mahasiswa, dunia politik, juga dunia jurnalistik. Banyak juga karya yang telah diciptakan oleh Sam Ratulangi berdasarkan pengalaman dan hasil pemikirannya. Sam Ratulangi sudah banyak berkontibusi untuk mempertahankan Sulawesi agar tidak jatuh ke tangan Belanda. Berkatnya, NKRI yang dahulunya memiliki sebutan "Hindia-Belanda" kini berganti menjadi "Indonesia".

\section{DAFTAR PUSTAKA}

Blumberger, J. Th. P. (1931). De Nationalistische Beweging in NerderlanschIndië. Haarlem: Tjeenk Willink

Geometry, R., \& Analysis, G. (1949). Sam Ratulangi. Plant Physiology, 1(1), $11-19$. 
Hatta, Moh. (2011). Untuk Negeriku: Bukittinggi-Rotterdam Lewat Betawi (vol. 1). Jakarta: Penerbit Buku Kompas.

Herdiana. (2013). Sitou Timou Tumou Tou Sebagai Wujud Misi Gereja. Journal of Chemical Information and Modeling, 53(9), 1689-1699. https://doi.org/10.1017/CBO9781107415324.004

Hermiyanty, Wandira Ayu Bertin, D. S. (2017). Persaingan Elit Bangsawan dengan Kelompok Terdidik pada Masa Revolusi di Sulawesi Selatan. Journal of Chemical Information and Modeling, 8(9), 1-58. https://doi.org/10.1017/CBO9781107415324.004

Iii, B. A. B. (2013). Theodorus Pangalila, 2013 Pengaruh Internalisasi Nilai Budaya Si Tou Timou Tou, Mapallus Dan Torang Samua Basudara Dalam Pelajaran Pkn Terhadap Peningkatan Sikap Toleransi Siswa Universitas Pendidikan Indonesia | repository.upi.edu. 63-88.

Ingleson, John. (1983). Jalan ke Pengasingan: Pergerakan Nasionalis Indonesia Tahun 1927-1934. Jakarta: LP3ES.

Laessach M Pakutawo, Mustari Busro, A. (2014). Negara Boneka Belanda (Negara Indonesia Timur) 1945- 1950. Jurnal Pattinggalloang, 5(1), $27-37$.

Matematika, P., Keguruan, F., Ilmu, D. A. N., \& Siliwangi, U. (2015). Matematikawan pertama asal indonesia.

Nalenan, R. (1981). Arnold Mononutu: Potret Seorang Patriot. Jakarta: Gunung Agung.

Nasution, S. (2011). Strategi pendidikan belanda pada masa kolonial di indonesia. Ihya Al-Arabiyah: Jurnal Pendidikan Bahasa Dan Sastra Arab, 2(2), 254-258.

Nathan, A. J., \& Scobell, A. (2012). How China sees America. Foreign Affairs, 91(5), 1689-1699. https://doi.org/10.1017/CBO9781107415324.004

Poeze, Harry. (2008). Di Negeri Penjajah: Orang Indonesia di Negeri Belanda 1600-1950. Jakarta: Gramedia.

Prof.C.P.F. Luhulima. (1937). Pembahasan buku Dr. G.S.S.J. Ratu Langie: Indonesia in den Pacific Kernproblemen van den Aziatischen Pacific. Zhurnal Eksperimental'noi $i$ Teoreticheskoi Fiziki, 21-34. http://mobile.kwansei.ac.jp/s_hws/attached/0000052629.pdf\%5Cnhttp://schol ar.google.com/scholar?hl=en\&btnG=Search\&q=intitle:No+Title\#0

Ratulangi, S. J., Saul, G., \& Jacob, S. (2019). Game 2 Dimensi Tentang Sam Ratulangi Sebagai Pahlawan Nasional. Jurnal Teknik Informatika, 13(4), 112. https://doi.org/10.35793/jti.13.4.2018.28095

Salim, D. (2017). Pusat Kebudayaan. June 1949, 350938. https://docplayer.info/60194214-Tinjauan-pustaka-pusat-kebudayaan-dangaya-arsitektur-indis-bab-3-tinjauan-pustaka-pusat-kebudayaan-dan-gayaarsitektur-indis.html

Saul, G., Jacob, S., Ratulangi, S., Utara, S., \& Manado, U. (1949). Sam ratulangi. November 1890 .

Utama, W. S. (2018). Mempropagandakan Kemerdekaan di Eropa: Perhimpunan Indonesia dan Internasionalisasi Gerakan Antikolonial di Paris. 1(2), 25-45. 